\title{
The Enhancement of Regional Disaster Management Agencies (BPBD) of Sumbawa Regency's Capability in Flash Flood Management Through Aid Assistance of Japan International Cooperation Agency (JICA)
}

\author{
Nudia Vebina Ayumahani ${ }^{1}$ \\ Dina Ruslanjari ${ }^{2}$
}

\begin{abstract}
The need for enhancing capability has a very important significance in effective disaster management activities. Regional Disaster Management Agencies (BPBD) of Sumbawa Regency established cooperation with the Japan International Cooperation Agency (JICA) in enhancing the capability of flash flood management. The purpose of this research was to review and evaluate the JICA's aid assistance programs toward BPBD of Sumbawa Regency, hereafter analyze the impact of the programs. Evaluation and analysis of this research were measured by three indicators of capability which is resources, leadership and policy implementation. This research used a qualitative descriptive method and proceed through the source and method triangulation. The researcher used purposive sampling technique in choosing seven informants from BPBD of Sumbawa Regency's staff. The results showed that JICA's aid assistance programs towards BPBD of Sumbawa Regency had been achieved by the targets and goals that have been determined. This program has impacted on enhancing the capability of resources that leads to the ability in Mapping, Technical Guidelines (JUKNIS) and Disaster Management Plan (RPB). Increasing the capability of Human Resources (HR) gives the effect of increasing capability in other fields such as financial resource capability, technical resource capability, leadership capability and policy implementation capability. The main factors in the success of the capability enhancement are the discipline factor of BPBD staff, high willingness to improve capability by BPBD staff, capabilityenhancing programs, and clear direction from JICA.
\end{abstract}

\section{Keywords:}

capability; aid assistance; flash flood.

\section{Introduction}

Disaster becomes a natural phenomenon which frequently occurs in Indonesia and commonly not a new term. A natural phenomenon considered to be a disaster if it has number or loss and risk (UU RI 24/2007). In this case, capability enhancement needs to be improved to reducing and tackling disasters to prevent problems becoming more complex when confronted with impacts. Regarding disaster management, all government elements should have definite roles and policies to address and mitigate disaster risk (Kusumasari, 2014). Therefore, depart from the need for disaster

\footnotetext{
${ }^{1}$ Magister of Disaster Management, Graduate School, Universitas Gadjah Mada

Email: nvyuma@mail.ugm.ac.id \& ayuma_honeru@yahoo.com

${ }^{2}$ Magister of Disaster Management, Graduate School, Universitas Gadjah Mada

Email: dienarus@ugm.ac.id \& ruslanjari.dina@gmail.com
} 
Nudia Vebina Ayumahani, Dina Ruslanjari, The Enhancement of Regional Disaster Management Agencies $(B P B D)$ of Sumbawa Regency's Capability in Flash Flood Management Through Aid Assistance of Japan International Cooperation Agency (JICA)

Table 1.

Fast Flooding Record in Sumbawa Regency

\begin{tabular}{|c|c|c|}
\hline No & Date & Location \\
\hline 1 & 28 March 2015 & Taliwang District \\
\hline 2 & 1 January 2011 & Buer District \\
\hline 3 & 6 March 2011 & Brang Kolong Village Plampang District \\
\hline 4 & 28 March 2011 & $\begin{array}{l}\text { Bangkong Sub-Village Karang Dima } \\
\text { Village Labuhan Badas District }\end{array}$ \\
\hline 5 & 1 April 2011 & $\begin{array}{l}\text { Several Villages in Alas District such as } \\
\text { Gontar, Usar Mapin, Mapin Kebak, Labu } \\
\text { Mapin and Mapin Rea }\end{array}$ \\
\hline 6 & 14 April 2011 & $\begin{array}{l}\text { Sepayung Village Plampang District } \\
\text { and in several Sub district in Sumbawa } \\
\text { District such as Brang Biji, Bugis and } \\
\text { Brang Bara }\end{array}$ \\
\hline 7 & 8 May 2011 & Orong Bawa Village Utan District \\
\hline 8 & $\begin{array}{l}13-17 \text { March } \\
2012\end{array}$ & Tero Jotang Sub-Village Empang District \\
\hline
\end{tabular}

Kakiang Village Moyo Hilir District

Disaster occurs precisely after the 2011 new year celebration on Saturday $1^{\text {st }}$ of January at 02.30 WITA. In this instance, one died victim, 29 houses drifting, 36 severe houses damage, and 21 houses damage

istrict -

Mama Village Lopok District

Berora Village Lopok District

Lopok Village Lopok District

Impact on one broken bridge with 19 meters length and 4 meters width which connects Jotang and Tero Villages, thus emergency bridge was built

Impact on one victim caught in the river flow and have been evacuated. The village area of Kakiang, Geru, Sengkal, and Maili submerged by flash floods Impact on two drifting people with status of 1 person has been found alive, and one person found a death Impact on 109 submerged houses, one drifting house and 1 Middle School (SMP) that has been submerged Five submerged Sub-Villages with 2 meters height impacting houses such as Lopok Bawah with 80 houses, Lopok Atas 25 houses, Temung Jangi 20 houses, Kemang Kuning 20 houses, and Bage Tango 5 houses

Labuhan Kuris Village Lape District

Flash flood reached 1,5 meters height causing 36 houses submerged in Labuhan Kuris Sub-Village, 69 houses submerged in Ai Mual Sub-Village, 16 houses submerged in Katanga Sub-Village and 20 houses submerged in Kuris Sub-Village

Karang Dima Village Labuhan Badas Impact on the Head Office Karang Dima Village District submerged, the bridge located in front of Jayani Hotel broke out due to culverts clogged with garbage carried by a flash flood, thus the water overflowed up to the road, and 13,98 Ha of the farmland area threatened harvest failure in Batu Nisung Sub-Village

Kauman Sub-Village Labuhan Village Impacted 95 houses submerged

Labuhan Badas District

Untir Iwes District

29 houses submerged in Nijang Village, 23 hectares of paddy fields ready for harvest submerged and about 115 meters of culvert damaged

Tepal Village Batulanteh District Impact on one broken bridge with 20 meters length, 50 meters broken road (severely damaged), 13 cows lost, 24 houses moderately damaged, six houses severely damaged, one room in Semongkat Elementary School with damaged roof and six rooms in Ladan Elementary School moderately damaged 
connection from page 57

9 16 March 2012 Senawang Village Orong Telu District

Two drifting people (Hatnawati \pm 38 years old and Hadijah/Sija \pm 56 years old) have been found 100 meters from the scene and one bridge (Senawang 1) broken and severely damaged

Source: BPBD Kabupaten Sumbawa, 2013; Sursiyamtini dan Maria, 2013

management in regions and implementing provisions of article 18 and 19 of UndangUndang Nomor 24 Tahun 2007, the government needs to form Regional Disaster Management Agency (BPBD) ${ }^{3}$ (PERKA BNPB 3/2008). These needs are supported by Peraturan Menteri Dalam Negeri Nomor 46 Tahun 2008 that in each Province established BPBD Province and in each Regency/Municipality can be established BPBD Regency/Municipality.

The government of Sumbawa Regency established BPBD in 2010 ago and actively institutionalized in 2011 to deal with regional disaster problem. The disaster which often arises in Sumbawa Regency is a flash flood. This flash flood does not cause many casualties, but the damage is seen from the house's condition (BPBD Kabupaten Sumbawa, 2013). Flash flood often takes place in Sumbawa Regency at the beginning of the year and the end of the year. The intensity of this disastrous event began to upsurge in early 2011.

The most responsible party in disaster management is Regional and Central Government, but this cannot be done merely by sole actor or institution. The government of Sumbawa Regency still lack capability in handling the issue of disaster even have undergone some training to improve their actions. ${ }^{4}$ According to records in Table 1 Sumbawa Regency has numerous flash flood events. These circumstances make them require the existence of another party in handling the issues.

${ }^{3}$ BPBD refers to abbreviation of Badan Penanggulangan Bencana Daerah

${ }^{4}$ Lack of capability due to low background about managing disaster especially flash flood. (Conclusion of several interviews form BPBD staffs)
It is necessary for the involvement of several (multiple) agencies to handle this issue. They involve international agency such Japan International Cooperation Agency (JICA) which also has an assistance project entitled "The Project for Enhancement of the Disaster Management Capacity of $\mathrm{BNPB}^{5}$ and $\mathrm{BPBD}^{\prime \prime}$ to deal with the issue of a flash flood. Cooperation between those has been established for approximately 19 months since April 2014 to October 2015.

The purpose of this research was to 1) review and evaluate the JICA's aid assistance programs toward BPBD of Sumbawa Regency's capability in managing flash flood; hereafter 2) analyze the impact of the programs as well as the factors that influence it.

\section{Foreign Aid}

Morgenthau (1962) stated that foreign aid consists of 6 types such as humanitarian, subsistence, military, bribery, prestige, and economic development. Arsdale and Nockerts (2008) simply describe humanitarian is passed the country's border to help those in need. ${ }^{7}$ Foreign aid such humanitarian has a precise close bond with disaster issues as implemented by JICA to BPBD of Sumbawa Regency. Japanese government makes humanitarian aid to third world countries or developing countries as their instruments in foreign policy. Facing the issues of disaster, Japanese

\footnotetext{
${ }^{5}$ BNPB is National Disaster Management Agency, which refers to abbreviation of Badan Nasional Penanggulangan Bencana.

${ }^{6}$ https://www.jica.go.jp/project/english/indonesia/010/ outline/index.html

${ }^{7}$ https://sites.tufts.edu/jha/archives/138
} 
Nudia Vebina Ayumahani, Dina Ruslanjari, The Enhancement of Regional Disaster Management Agencies $(B P B D)$ of Sumbawa Regency's Capability in Flash Flood Management Through Aid Assistance of Japan International Cooperation Agency (JICA)

government puts their trust on JICA as one of agency or institution that have an important role in managing grant aid, loan aid and technical support from 1974 to $2003 .^{8}$

\section{Capability}

Based on Kusumasari, Alam, \& Siddiqui (2010), Amit \& Shoemaker (1993) stated that capability is an organizational capacity in mobilizing resources by combining and using organizational processes to influence chosen goals. Cigler, 2007 (in Kusumasari et al., 2010) defines capabilities as capacities comprising financial, technical, policy implementation, institutional, leadership, and human resource capacities. Triawan et al. (2012) also conclude several capacity variables from several sources such as Patton \& Sawicki (1986), Soeprapto (2005), UNDP (2009) and World Bank (2010), which is comprised into Regulations, Organizational Commitments, Apparatus, Financing, and Capacity Organization. Based on prior research sources about capability, the researcher then took three main variables including Resources, Leadership and Policy Implementation.

\section{Capability of Resources}

The resource itself is an input that forms the basis of analysis in the production proses (Grant, 1991; Fasichach, 2013). Quoted from Kusumasari (2010), organizational resources are assets owned by an organization (Barney, 1991), competence and organizational capabilities (Staljk, Evans, and Shulman, 1992) as well as knowledge (Grant, 1996; Liebeskind, 1996; Spender and Grant, 1996). Hill and Jones, 1992 (in Hitt, Irlandia, and Hoskisson, 1997; Kusumasari, 2014) explain that resources are the attributes of financial, physical, individual and organizational capital that become the basic capital of the organization. Dimensions of capability that have been shared by Leonard-

\footnotetext{
${ }^{8}$ https://www.jica.go.jp/english/about/history/index.html
}

Barton, 1992 (in Kusumasari, 2014) in the form of knowledge and skills, managerial systems, values, and norms, as well as the overall technical brief in resources. Based on the understanding of the resources described above, this study pursued the indicator of resources into human resources, financial and technical.

\section{Capability of Leadership}

This capacity is related to leadership, power relations and social norms (values, incentives, motivation, trust, legitimacy, transparency), the organizational ability to engage, produce results and manage change, and provide relevant rewards and incentives, to adapt and update themselves (UNDP, 2009). Yukl, 1989 (in Wibowo, 2011) reveals that leadership has an important role in changing the performance a unit, agency or organization; as well as being a factor in the success of an organization.

\section{Capability of Policy Implementation}

This capacity includes internal legislation policies, systems and strategies, rules, procedures and frameworks that enable run by organization along with the achieved mandate (UNDP, 2009). Capacity to formulate policies and strategies set goals on how a vision and mandate will be implemented, make relevant organizational implementation strategies, and formulate policies both sectorally and across sectors (UNDP, 2009). Well formulated policy needs to be implemented to achieve the desired vision and mandate, with the aim that the stages of policy implementation become crucial in improving the capability of an institution.

\section{Institutionalism Theory}

Institutionalism has been widely used in defining individual and institutional actions (Dacin, Goodstein, \& Scott, 2007; Kusumasari, 2014). The organization is a technical instrument 
that is structured in such a way for a particular purpose. BPBD Sumbawa Regency is formed in such a way as to achieve a specific goal of disaster risk reduction in the Sumbawa Regency. The importance of an institution is also explained by Douglas, 1986 (in Lassa, 2010) that disaster risk reduction requires institutions to determine the life or death of a person.

\section{Evaluation Theory}

Evaluation becomes the process of program assessment that aims to know whether the program can be run or not with a series of information that has been obtained during the evaluation process. Evaluation determines how successful intervention is and identifies the improved parts (Pal, 2014, Guyadeen and Seasons, 2016).

\section{Program Evaluation}

According to Stufflebeam and Shinkfield, 2007 (in Wirawan, 2011) the definition of the program evaluation theory is "A program evaluation theory is a coherent set of conceptual, hypothetical, pragmatic, and ethical principles forming a general framework to guide the study and practice of program evaluation." Program evaluation is a systematic method that aims to collect, analyze, and use the information to answer basic questions about the program (Wirawan, 2011). In this study, the evaluation conducted by the researchers is a systematic evaluation, because researchers need to identify the extent to which the program of aid assistance from JICA increased capability BPBD of Sumbawa Regency has achieved its objectives by the predetermined and expected impact that proportional to the effort that has been made.

\section{Evaluation Measurement}

In a program, Wirawan (2011) describes many programs that constitute a systematic and visual way of presenting and sharing about the relationships between the resources that must be executed in the program, the activities to be performed, and the expected changes or results will occur. The researcher classified the evaluation into several indicators based on Wirawan (2011), Badjuri and Yuwono (2002), and Altahus, Bridgman, and Davis (2013). This indicator aims to measure an evaluation consisting of inputs, processes, outputs, and outcomes.

\section{Methods}

This research used a qualitative descriptive method. This method produces descriptive data in the form of written words and oral from people and describes the behavior, perspective or expressions of emotion from informants, thus providing an objective picture and explain the facts of phenomena that occur in the field by using existing theories to be able to analyze the phenomenon (Moleong, 2005). From this approach, the researcher will analyze the improvement of BPBD of Sumbawa Regency in managing flash flood through cooperation with JICA.

\section{Location of Research and Informant}

This research was conducted at Regional Disaster Management Agency (BPBD) of Sumbawa Regency, Nusa Tenggara Barat. Sumbawa Regency was chosen as the location of the research with the consideration that Sumbawa Regency has the threat of flash flood and has caused severe damage and losses based on Disaster Management Data Information of Sumbawa Regency published by BPBD of Sumbawa Regency in 2014. The researcher used purposive sampling technique in choosing seven informants from BPBD of Sumbawa Regency's staff.

\section{Data Collection Technique}

Collecting data turn into the main thing in the study, because it aims to obtain data by predefined data standards (Sugiyono, 2011). Sugiyono explained there are several 
Nudia Vebina Ayumahani, Dina Ruslanjari, The Enhancement of Regional Disaster Management Agencies $(B P B D)$ of Sumbawa Regency's Capability in Flash Flood Management Through Aid Assistance of Japan International Cooperation Agency (JICA)

techniques for collecting data such as observation, interview, and documentation. These techniques are used by researcher to collecting the data.

Observation is direct monitoring of the phenomena to be studied by researchers in the place to be the object of research. In this research, observation is used to collect data about JICA assistance programs in enhancing capability of BPBD of Sumbawa Regency. Interviews are the process of seeking information through questions posed directly to the source of information in depth. Indepth interviews were conducted to establish direct communication to obtain the necessary information and by the research.

Documentation is done by examining written sources related to the subject matter. Documentation is used to retrieve data and information. The source of documents that researcher use in this study is Rencana Aksi, Rencana Kontijensi, Rencana Penanggulangan Bencana, Peraturan Daerah dan Peraturan Bupati Kabupaten Sumbawa about Regional Disaster Management Agency, Undang-Undang Republik Indonesia Nomor 24 Tahun 2007 about Disaster Management Implementation, Peraturan Pemerintah Republik Indonesia Nomor 22 Tahun 2008 about Funding and Management of Disaster Aid, Peraturan Pemerintah Republik Indonesia Nomor 23 Tahun 2008 about Participation of International Organization and Foreign Non Govermantal Organization in Disaster Management, Peraturan Menteri Dalam Negeri Republik Indonesia Nomor 46 Tahun 2008 about Guidelines of Organizational and Work Procedures for Regional Disaster Management, as well as books, journals, papers and other data and documents about capability of BPBD of Sumbawa Regency.

\section{Data Analysis}

Qualitative data analysis is an action done by organizing and sorting the data into a form that can be processed, synthesized, searching and finding patterns, determine the critical points that can be learned, then decide what can be presented to the public. The process of analysis carried out since the beginning of research through data reduction stage, presenting and verifying data which ended with the conclusion of data (Sugiyono, 2011). This research was conducted by observing general condition of BPBD of Sumbawa Regency and its capability before receiving JICA aid assistance. After figuring out the conditions, the researcher reviewed the assistance programs provided by JICA in enhancing the capability to managing flash flood, then evaluated the program achievement. The next stage, the researcher analyzed the impacts of influence resulting from JICA's aid assistance toward the capability of BPBD of Sumbawa Regency on each capability component such as resources, leadership, and policy implementation, which have been summarized as an indicator of capability from various expert sources.

\section{Validity of Data}

In justifying the truth of a research data obtained in the field, the validity of data is significant to do. The examination of validity/ credibility in the research is done by triangulation. Triangulation is a data checking technique that utilizes something else outside the data for checking purposes or as a benchmark against the data itself (Akbar \& Usman, 1995). Triangulation used in this research is source triangulation and method triangulation. Sources triangulation means comparing and rechecking degrees of trust or information obtained from different sources through different times (Moleong, 2005). Method triangulation is done by comparing data obtained through interviews with documentation obtained by the researcher or vice versa.

\section{Result and Discussion}

\section{Location Description}

Topographically, Sumbawa Regency is dominated by the uneven ground level or 
tends to be hilly with a height of about 0 to 1,730 meters above sea level. The climate is a tropical climate with the influence of El Nino and La Nina phenomena of the Pacific Ocean. In certain months, at the beginning of 2013, the number of rainy days in January was 24 days with $446.0 \mathrm{~mm}$ of rainfall (Badan Pusat Statistik Kabupaten Sumbawa, 2014).

Tabel 2.

\section{Number of Rainy Days, Rainfall and Evaporation Detailed per Month in Sumbawa Regency 2013}

\begin{tabular}{cccc}
\hline Month & $\begin{array}{c}\text { Rainy } \\
\text { Days }^{9}\end{array}$ & $\begin{array}{c}\text { Rainfall } \\
\text { (mm) }\end{array}$ & $\begin{array}{c}\text { Evaporation } \\
\text { (mm) }\end{array}$ \\
\hline January & 24 & 446,0 & 148,5 \\
February & 13 & 335,0 & 140,4 \\
March & 9 & 190,0 & 151,4 \\
April & 11 & 100,0 & 151,2 \\
May & 8 & 99,0 & 154,8 \\
June & 11 & 139,0 & 142,0 \\
July & 2 & 3,0 & 149,7 \\
August & - & - & 191,8 \\
September & - & - & 202,3 \\
October & 1 & 5,0 & 208,9 \\
November & 7 & 66,0 & 173,2 \\
December & 18 & 237,0 & 171,6 \\
Total & 104 & $1.620,0$ & $1.985,8$ \\
\hline
\end{tabular}

Source: Badan Meteorologi, Klimatologi dan Geofisika Kabupaten Sumbawa; BPS ${ }^{10}$ Kabupaten Sumbawa, 2014

Evaporation has a significant influence on rainy days and rainfall since the amount of evaporation can have an impact on many rainy days and precipitation that occurs in the next period. In Table 2 the significant amount of evaporation occurred at the end of 2013 and accumulated rainfall in early 2014, i.e., January.

Based on Disaster Management Data Information of Sumbawa Regency (BPBD Kabupaten Sumbawa, 2014), areas that prone to floods in Sumbawa are Brang Moyo in Poto Tengke Moyo Hilir, Brang Beh in Lunyuk,

\footnotetext{
${ }^{9}$ Rainy Days means day with the incidence of rain $\geq 1$ millimeter

${ }^{10} \mathrm{BPS}$ refers to abbreviation of Badan Pusat Statistik
}

Brang Labuhan Mapin in Alas, Brang Utan in Utan Rhee, Brang Muir in Plampang, Empang, Moyo Hulu, Ropang, Lape, and Lopok. Those vulnerable areas may pose a disaster risk if many residents live in the area and become victims of natural disasters.

\section{An Overview of the Regional Disaster Management Agencies (BPBD) of Sumbawa Regency before Aid Assistance Program of Japan International Cooperation Agency (JICA)}

The reason for Sumbawa Regency area is vulnerable to disaster, caused by natural, nonnatural or human nature, due to the condition of a solid and heterogeneous area. This can be a threat to regional security if not properly managed.

“G e o g r a p hi c a 11 y a n d demographically, Sumbawa Regency often experienced disasters such as floods, earthquakes, volcanoes as well as tectonic, tsunamis, coastal erosion/abrasion, strong winds, landslides, fires, environmental pollution, social conflicts and disease epidemics. Disaster management in past days only as "reactive" despite many disasters, thus ineffective and efficient. All of the countermeasures are often unaccountable behind the desk, so the impression is so slow as people, who become victims, often complain about. Moreover, the allocation of funds for Disaster Mitigation is often inadequate when faced with the needs and demands of the public, so the impression is very bureaucratic. On the other hand assets in the form of human resources and infrastructure facilities of Sumbawa Regency need to be protected to create a sense of security and comfort while increasing the resilience to disaster threats and risks." 11 (BPBD Kabupaten Sumbawa, 2014)

\footnotetext{
${ }^{11}$ This quote is the opening statement of the chief executor of BPBD of Sumbawa Regency in meeting presentation with the Japan International Cooperation Agency (JICA).
} 
Nudia Vebina Ayumahani, Dina Ruslanjari, The Enhancement of Regional Disaster Management Agencies $(B P B D)$ of Sumbawa Regency's Capability in Flash Flood Management Through Aid Assistance of Japan International Cooperation Agency (JICA)

To achieve the preferred conditions, prevention and mitigation capabilities need to be improved to make disaster prevention activities that are beneficial to every element in Sumbawa Regency. Indeed, these conditions have a close relationship with the existence of disaster management institutions, namely the Regional Disaster Management Agency (BPBD) of Sumbawa Regency, which has the authority to assist the Sumbawa Regent to tackle regional disasters for realizing good governance.

\section{Human Resources (Apparatus)}

Regional Disaster Management Agency of Sumbawa Regency has information on human resources as follows.

a. The number of employee consists of 43 staff consisting of 33 Civil Servants, 10 Personnel Honorary / Non-Permanent Employee (PTT). ${ }^{12}$

b. Regarding education, it is still inadequate and needs to develop disaster management knowledge. This is supported by statements from several informants about the lack of insight into the science of disaster.

"The quality of BPBD human resources is still low. This is coupled with the condition of BPBD staff who do not understand about the disaster itself. Also, BPBD staff are not experts in preparing Disaster Map, Disaster Manual and Technical Guidelines (JUKNIS)"13 (Source: Analysis Result, 2018) ${ }^{14}$

c. Regarding work experience, most have not understood about disaster management. This is based on the educational background and work experience of the staff of BPBD of Sumbawa Regency. The information gained as a result of interviews with informants

${ }^{12}$ PTT refers to abbreviation of Pegawai Tidak Tetap. ${ }^{13}$ JUKNIS refers to abbreviation of Petunjuk Teknis.

${ }^{14}$ The statement is the conclusion of some interviews from some informants. about staff education background and work experience of BPBD of Sumbawa Regency is stated in the following statement.

"BPBD staffs have varied educational background, such as High School, Diploma IV, and Bachelor degree from Agriculture and Livestock, Social Welfare, Governmental Science, and some are mutation result" (Analysis Result, 2018)

Based on the results of interviews and analysis, can be seen that BPBD of Sumbawa Regency staff, who has a position as Head of every organizational element, do not have any disaster knowledge at the beginning of work. Inadequate knowledge of disaster is a factor of weak Human Resources Capability in BPBD of Sumbawa Regency. Under such circumstances, BPBD is still able to fulfill its obligations as a disaster agency focusing on managing disasters. This can be seen from the formation of Quick Reaction Team (TRC) ${ }^{15}$ in 2011.

\section{Facilities and Infrastructure}

Facilities such as buildings, office infrastructure, mobility facilities, and telecommunication facilities are still quite adequate until these days. These facts are based on information from BPBD staff that describes some facilities for the flash flood management that is owned by BPBD of Sumbawa Regency. The following is an excerpt from the interview with Mr. Ir. Mukmin, M. Si as the Chief Executive of BPBD Sumbawa Regency.

“...yeah, we do have transportation, one tank car, then there is six suction machine, including operational car, including also a light tower that is a light transmitter in case of disaster. So, the light tower can be used, the variety of life vest, then six rubbers, including also one evacuation boat. Last year we will get a boat because

\footnotetext{
${ }^{15}$ TRC refers to abbreviation of Tim Reaksi Cepat.
} 
the capacity of the previous boat only fits ten people. However, I ask again to Emergency Director to get the bigger one, which can fit 30 people.

...yeah, hope we will get those facilities, we also ask multipurpose truck. I have already signed for three multipurpose trucks..." (7 January 2018)

Facilities in the form of documents have been made by BPBD in case of managing flood, among others, Formation of Action Plan in the form of Module TSBD ${ }^{16}$ (Village Disaster Preparedness Team), Rencana Kontijensi Bencana Banjir Desa Baru Tahun 2013, Flood Risk Map in 6 Project Villages between OXFAM and BPBD, Early Warning System Document of Kukin Village, and Document of Study Results of Participatory Capacity and Vulnerability Based on Community-Based Disaster Risk in Sengkal Sub-Village, Batubangka Village.

\section{Source of Funding and Financial Policy}

Regional Disaster Management Agency as one of the regional technical institutions in carrying out its activities starting in the fiscal year 2011 is supported by 2 sources of financing, $A P B D(D P A-S K P D)$ and $A P B N$ (Tugas Pembantuan - TP), while for the fiscal year 2014 the source of financing is only in APBD II (DPAP - SKPD). ${ }^{17}$ Budget owned by BPBD of Sumbawa Regency from 2011 to 2014 have a precisely good improvement. Further down is the budget data of BPBD in 2011-2014 (BPBD, 2015).

a. The fiscal Year 2011, Total: IDR 647,473,515

b. The fiscal Year 2012, Total: IDR 3,188,842,280

c. The fiscal Year 2013, Total: IDR 5,258,329,091 $(\text { DAMKAR })^{18}$

\footnotetext{
${ }^{16}$ TSBD refers to abbreviation of Tim Siaga Bencana Desa.

${ }^{17}$ APBD refers to abbreviation of Anggaran Pendapatan Belanja Daerah. DPA refers to abbreviation of Dokumen Penggunaan Anggaran. SKPD refers to abbreviation of Satuan Kerja Perangkat Daerah. APBN refers to abbreviation of Anggaran Pendapatan Belanja Nasional.

${ }^{18}$ DAMKAR refers to abbreviation of Pemadam Kebakaran (Fire Company)
}

d. The fiscal Year 2014, Total: IDR 4,760,812,775 (DAMKAR)

\section{Aid Assistance Program of Japan International Cooperation Agency (JICA) toward BPBD of Sumbawa Regency}

\section{Aid Assistance Process}

Nusa Tenggara Barat Province was selected as the 2nd Pilot Province of the project. Based on the program title, it can be concluded that the objectives of JICA's program enhancing disaster management capacity of BNPB, the provincial BPBDs as well as the Regency/ Municipality BPBDs beside the pilot areas. Here is a general diagram of JICA capacity building project organization.

Technology Transfer is done through Workshop conducted once or twice per month, On the Job Training (OJT), Counterpart Training in Japan. Partners or commonly called Counterparts (CP) by JICA consist of BNPB, BPBD of North Sulawesi Province along with BPBD Regency/ Municipality, and BPBD Nusa Tenggara Barat Province along with BPBD Regency/Municipality. Counterparts from BPBD of Sumbawa Regency are then elaborated by the selecting the members on every planned output.

Every CP will be trained by the JICA to conduct the program and produce outputs by the planned. The CP undergo a two week training period in Japan.

\section{Output Program}

Based on Table 3, JICA has four outputs to be achieved on this program, here is the explanation below (Kobayashi, 2013).

a. Output 1:Management/Disaster Information Data. P Capacity enhancement of Regency/ Municipality BPBDs in collecting disaster data and increasing data accuracy. The collection and management of disaster data or information is a very basic thing in disaster management. Disaster data or information is collected properly and correctly using the DIBI (Indonesia Disaster 
Nudia Vebina Ayumahani, Dina Ruslanjari, The Enhancement of Regional Disaster Management Agencies $(B P B D)$ of Sumbawa Regency's Capability in Flash Flood Management Through Aid Assistance of Japan

Picture 1.

JICa Project Organization

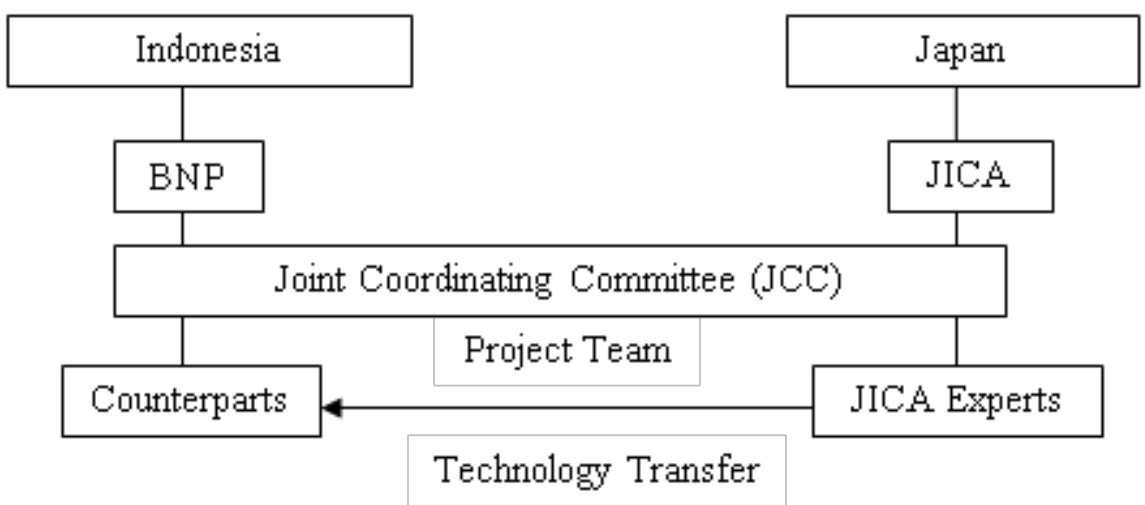

Source: Kobayashi, 2013

Table 3.

Counterpart Output Program JICA Terhadap BPBD Kabupaten

Sumbawa

\begin{tabular}{ll}
\hline \multicolumn{1}{c}{ Output } & \multicolumn{1}{c}{ Positions and Personel } \\
\hline Management & Team leader: Ir. Mukmin, M.Si \\
& Coordinator: Drs. Hj. Huriah \\
Output 1 Management/Disaster Information Data & Member: \\
& 1. Dra. Huriyah \\
& 2. Supri, S.T \\
Output 2 Disaster Risks Map & Member: \\
& 1. Moh. Ganefi, A.Pi \\
& 2. Rahmat \\
& 3. Jalaludin \\
Output 3 Regional Disaster Management Plan and & Member: \\
Action Plan & 1. Abdul Rauf, S.Sos \\
& 2. Siti Aminah, S.T \\
& 3. Supri, S.T \\
Output 4 Community-Based Disaster Risk Reduction & Member: \\
(PRBBK) ${ }^{19}$ & 1. Drs. Usman Amin \\
& 2. Syamsuddin Nur \\
& 3. Turino Junaidi, S.Sos \\
\hline
\end{tabular}

Source: Amin, 2014

Information Data) ${ }^{20}$ system format for emergency response operations as well as non-disaster situations.

b. Output 2: Disaster Risks Map. Preparation of Disaster Hazard and Risk Map at the Regency/Municipality level in the target area. Understanding the types and extent of possible disasters is fundamental to

\footnotetext{
${ }^{19}$ PRBBK refers to abbreviation of Pengurangan Risiko Bencana Berbasis Komunitas.

${ }^{20} \mathrm{DIBI}$ refers to abbreviation of Data Informasi Bencana Indonesia.
}

disaster management, so that preparedness and mitigation efforts can be well implemented. The activity of identifying the level of threat or risk that poured in the form of hazard and risk map aims to prepare the Disaster Management Plan as well as the Community Based Disaster Risk Management (CBDRR).

c. Output 3: Regional Disaster Management Plan (RPB). ${ }^{21}$ Preparation of Regional

${ }^{21} \mathrm{RPB}$ refers to abbreviatoion of Rencana Penanggulangan 
Table 4.

Summary of BPBD Capacity Enhancement Activities in collaboration with JICA - JAPAN

\begin{tabular}{|c|c|c|c|c|c|}
\hline \multirow{2}{*}{ Output } & \multirow{2}{*}{ Objectives } & \multicolumn{2}{|c|}{ Workshop Schedule } & \multirow{2}{*}{ Resulting Product } & \multirow{2}{*}{ Required Data } \\
\hline & & 2014 & 2015 & & \\
\hline General & & --- & $\begin{array}{l}\text { June \& } \\
\text { September }\end{array}$ & $\begin{array}{l}\text { Checklist for } \\
\text { Capacity assessment }\end{array}$ & $\begin{array}{l}\text { 1. Laws and regulations related to } \\
\text { Disaster Management }\end{array}$ \\
\hline Output 2 & $\begin{array}{l}\text { Capacity } \\
\text { Enhancement of } \\
\text { BPBD in making } \\
\text { Disaster Hazard } \\
\text { and Risk Map }\end{array}$ & $\begin{array}{l}\text { June, } \\
\text { September, } \\
\text { October, } \\
\text { December }\end{array}$ & $\begin{array}{l}\text { April \& } \\
\text { June }\end{array}$ & $\begin{array}{l}\text { - Hazard \& Risk } \\
\text { Map } \\
\text { - Hazard \& Risk } \\
\text { Map Guidelines }\end{array}$ & $\begin{array}{l}\text { 2. APBD } 2014 \\
\text { 3. Budget of BPBD } 2014 \& 2015 \\
\text { 4. All SKPD } \\
\text { 5. Organizational structure of } \\
\text { BPBD, roles and functions, and }\end{array}$ \\
\hline Output 3 & $\begin{array}{l}\text { Capacity } \\
\text { Enhancement of } \\
\text { BPBD in making } \\
\text { Regional Disaster } \\
\text { Management } \\
\text { Plan and Action } \\
\text { Plan }\end{array}$ & $\begin{array}{l}\text { June \& } \\
\text { November }\end{array}$ & $\begin{array}{l}\text { January \& } \\
\text { April }\end{array}$ & $\begin{array}{l}\text { - JUKNIS of } \\
\text { Regional Disaster } \\
\text { Management Plan } \\
\text { - Action Plan of } \\
\text { Disaster Risk } \\
\text { Management } \\
\text { - Regional Disaster } \\
\text { Management Plan }\end{array}$ & $\begin{array}{l}\text { number of staff } \\
\text { 6. Regency of Sumbawa In Figures } \\
\text { (Latest) } \\
\text { 7. Latest RPJMD }{ }^{22} \\
\text { 8. RENSTRA Terbaru } \\
\text { 9. Disaster Management Plan (if it } \\
\quad \text { exist) } \\
\text { 10. Contingency Plan }\end{array}$ \\
\hline Output 4 & $\begin{array}{l}\text { Capacity } \\
\text { Enhancement of } \\
\text { BPBD in making } \\
\text { Community- } \\
\text { Based Disaster } \\
\text { Risk Reduction } \\
\text { (CBDRR) }\end{array}$ & $\begin{array}{l}\text { June \& } \\
\text { November }\end{array}$ & $\begin{array}{l}\text { January \& } \\
\text { April }\end{array}$ & $\begin{array}{l}\text { - PRB's Guideline } \\
\text { Community-Based }\end{array}$ & $\begin{array}{l}\text { 11. SOP } \\
\text { 12. List of disasters that have } \\
\text { occurred in the last } 5 \text { years } \\
\text { 13. Presentation/documents related } \\
\text { to disaster management } \\
\text { 14. General Information about } \\
\text { PUSDALOP } 23 \\
\text { 15. List of equipment/relief items } \\
\text { 16. Latest activities related to } \\
\text { disaster management } \\
\text { 17. Baseline data in villages for } \\
\text { analysis (population, group } \\
\text { vulnerability rate, GDP, type } \\
\text { and number of house and } \\
\text { public facilities, land use } \\
\text { conditions) } \\
\text { 18. Existing maps (topography, } \\
\text { geology, current hazards, } \\
\text { spatial plans, etc.) } \\
\text { 19. List of infrastructure (airports, } \\
\text { ports, bridges, etc.) } \\
\text { Ir. Mukmin, M.Si. }\end{array}$ \\
\hline
\end{tabular}

Source: BPBD Kabupaten Sumbawa, 2015

Disaster Management Plan for the Regional/ Municipality in the target area should be planned in order to provide maximum results.

d. Output 4: Disaster Management Simulation and Community-Based Disaster Risk Reduction (CBDRR). Disaster Management

Bencana.

${ }^{22}$ RPJMD refers to abbreviation of Rencana Pembangunan Jangka Menengah Daerah.

${ }^{23}$ PUSDALOP refers to abbreviation of Pusat Pengendalian Operasi.
Simulation is carried out in the target Province and also in the Regency/Municipality of target Province. Activities play an important role in the fluency implementation of emergency response operations. The first step in implementing the disaster management simulation is to plan and implement TTX (Table Top Exercise) and CPX (Command Post Exercise) to examine the SOP (Standard Operational Procedures) that have been prepared in this project. SOP will be revised if there is a problem in the 
Nudia Vebina Ayumahani, Dina Ruslanjari, The Enhancement of Regional Disaster Management Agencies $(B P B D)$ of Sumbawa Regency's Capability in Flash Flood Management Through Aid Assistance of Japan International Cooperation Agency (JICA)

implementation of the training. CBDRR is the key to mitigating the impact of disasters by educating the community in order to cope with the disaster.

\section{Impact Analysis}

The analysis of this study, based on the evaluation theory proposed by Wirawan and indicators of Badjuri and Yuwono, and Althaus, Bridgman, and Davis. The impacts received by the BPBD of Sumbawa Regency after obtaining the capacity building assistance program in managing flash flood by JICA, the staff of BPBD Kabupaten Sumbawa have better understanding about mapping as a whole such disaster mapping for one Regency of Sumbawa. Sumbawa Regency BPBD staff gain knowledge to make Disaster Management Plan (RPB) properly and correctly. BPBD already has Regional Disaster Management Plan of Sumbawa Regency 2014 - 2015 and Regional Disaster Management Plan of Sumbawa Regency 2015 - 2019.

As mentioned before, BPBD has formed TRC in 2011 with total 30 members, with the following year, exactly in 2012 member gained double into 60 members, and in 2013 it increased into 90 members. Nowadays, BPBD of Sumbawa Regency has 90 members TRC (BPBD, 2015).

In the financial sector, there are few improvements of funding, especially from government of Sumbawa Regency. The fund rise when there are big program/event, this point was supported by statement from Drs. Usman Amin as Head of Field 1 Prevention and Preparedness of BPBD of Sumbawa Regency.

"Yeah, just stagnant. It rises when we have the program from JICA. Fairly doubled up. That's all the money" (8 January 2018)

The statement above is supported by the financial data owned by BPBD. Here is the financial exposure of BPBD from 2015 to 2017. a. Fiscal Year 2015

Direct Expenditure : IDR 2,688,822,812

Indirect Expenditure : IDR 2,019,210,498

Total : IDR 4,708,033,310 (+ DAMKAR)

(Source: BPBD, 2015)

a. Fiscal Year 2016 : IDR 2,294,552,312

b. Fiscal Year 2017 : IDR 2,436,028,323

(DPA Kabupaten Sumbawa, 2017)

These data show the decreasing of BPBD's budget. It is because JICA program ended in 2015. Therefore BPBD does not have any big agenda in 2016 and 2017 as it did in 2015. The funds are sufficient enough to meet the activities of BPBD in disaster relief.

Another impact that occurred in BPBD Kabupaten Sumbawa along with other Government Institutions is legal products. BPBD can established the government regulations such as Peraturan Bupati Sumbawa Nomor 50 Tahun 2015 about Service Standards at the Regional Disaster Management Agency of Sumbawa Regency, Peraturan Daerah Kabupaten Sumbawa Nomor 5 Tahun 2016 about Disaster Management Implementation, and The issuance of Peraturan Bupati Nomor 21 Tahun 2017 on the Action Plan for Post-Disaster Rehabilitation and Reconstruction.

\section{Research Limitation}

This study focuses only on improving human resource capability, where enhanced capabilities in other fields such as financial resource capability, technical resource capability, leadership capability and policy implementation capabilities are automatically impacted. The capability enhancement of BPBD of Sumbawa Regency is further in the information system such as map-making, Technical Guidance (JUKNIS) and Disaster Management Plan (RPB), thus only a few to financial or emergency response and logistics. This limitation becomes a referral opportunity in the next program that will be conducted by BPBD of Sumbawa Regency with JICA or other partners. 


\section{Conclusion}

In this research, the enhancement of BPBD of Sumbawa Regency capability is measured by three indicators such as Resources, Leadership and Policy Implementation. Resources have variables such as Human Resources (HR), Financial and Technical. The results of this evaluation indicate that JICA's assistance program in enhancing capability has been achieved in accordance with the target and the objectives that have been determined and give a significant improvement impact from the capability of BPBD of Sumbawa Regency in managing flash flood through comparative analysis before, during and after JICA's aid assistance programs. These measurements show an increased capability in human resources that lead to BPBD staff capabilities in information systems such as map-making, Technical Guidelines (JUKNIS) and Disaster Management Plans (RPB). Increased capability in Human Resources (HR) affects the capability enhancement in other fields such as financial resource capability, technical resource capability, leadership capability and the capability of policy implementation. Based on the results of the analysis conducted in this study, the main factors that became the key to the success of increasing the capability of BPBD in Sumbawa Regency are disciplinary factors of BPBD staff, high willingness to improve capability by BPBD staff, capability improvement program, and clear direction from JICA.

The results of the research conducted by analyzing and evaluating the enhancement of capability at the Regional Disaster Management Agency (BPBD) of Sumbawa Regency through aid assistance program from Japan International Cooperation Agency (JICA), are expected to provide recommendations for improving the capability in managing flash flood in Sumbawa Regency. Suggestions that researcher able to contribute to improving the capability of institutions in managing flash flood through aid assistance programs are as follows. Researchers provide recommendations for this study, among others: 1) Routine training related to disaster management to improve the capability of BPBD officers of Sumbawa Regency, and not to close the possibility to conduct small training to the community, so that the people of Sumbawa Regency become a resilient community. Evaluation of programs that have been done regularly, so it can be input and recommendation against the shortcomings that exist in the future. 2) Renewal of disaster information especially disaster that is closely related to the region of Sumbawa Regency. 3) Socialization and dissemination of disaster information to disaster-prone areas in Sumbawa Regency through seminars or small visits. 4) The integration of disaster prevention and mitigation planning process is expected to be accommodated more in the regional budget. Therefore BPBD Kabupaten will not have any difficulties in making good quality program than before.

\section{References}

Akbar, P. S., \& Usman, H. (1995). Metodologi penelitian sosial. Jakarta: Bumi Aksara.

Althaus, C., Bridgman, J., \& Davis, G. (2013). The australian policy handbook. Singapore: KHL Printing Co. Pte Ltd.

Amin, U. (2014). Kick-off Meeting: BPBD Kabupaten Sumbawa (Rep.). Sumbawa: BPBD Kabupaten Sumbawa.

BPBD Kabupaten Sumbawa. (2013). Pengetahuan dan pedoman (membangun ketahanan Kab. Sumbawa menanggulangi bencana). Sumbawa: Pemerintah Kabupaten Sumbawa.

BPBD Kabupaten Sumbawa. (2015). Kondisi $B P B D$ dan PRB Kab. Sumbawa saat Ini. Sumbawa: BPBD Kabupaten Sumbawa.

BPS Kabupaten Sumbawa. (2014). Sumbawa dalam angka 2014. Sumbawa: BPS Kabupaten Sumbawa.

Fasichach, N. (2013). Analisis sumber daya dan kapabilitas PT Bank Tabungan Negara 
Nudia Vebina Ayumahani, Dina Ruslanjari, The Enhancement of Regional Disaster Management Agencies (BPBD) of Sumbawa Regency's Capability in Flash Flood Management Through Aid Assistance of Japan International Cooperation Agency (JICA)

(PERSERO) Tbk. dengan pendekatan Resource Based View (RBV) (Master's thesis, Yogyakarta, 2013). Yogyakarta: Universitas Gadjah Mada.

https://sites.tufts.edu/jha/archives/138

https://www.jica.go.jp/english/about/history/ index.html

https://www.jica.go.jp/project/english/ indonesia/010/outline/index.html

Kobayashi, I. (2013). Kick-off Meting: Penjelasan Proyek JICA (Rep.). Mataram: JICA Project Team.

Kusumasari, B. (2014). Manajemen bencana dan kapabilitas pemerintah lokal. Yogyakarta: Gava Media.

Kusumasari, B., Alam, Q., \& Siddiqui, K. (2010). Resource capability for local government in managing disaster. Disaster Prevention and Management Journal, 19(4), 438-451. doi: 10.1108/09653561011070367

Lassa, J. A. (2010). Institutional vulnerability an governance of disaster risk eduction: Macro, meso and micro scale assessmnent (With Case Studies from Indonesia) (Doctoral dissertation Rheinischen FriedrichWilhelms-Universität, 2010). Bonn, Germany: Rheinischen FriedrichWilhelms-Universität.

Moleong, L. J. (2005). Metode penelitian kualitatif. Bandung: Remaja Rosda Karya.
Morgenthau, H. J. (1962). A political theory of foreign aid. American Political Science Review, 56(2), 301-309. doi: 10.2307/1952366

Passing Out Program, Sumbawa. (2014). Memperkuat ketangguhan masyarakat terhadap bencana di Indonesia Timur (Kabupaten Sumbawa). Sumbawa: OXFAM.

Peraturan Kepala BNPB Nomor 3 Tahun 2008 tentang Pedoman Pembentukan Badan Penanggulangan Bencana Daerah. Jakarta.

Sugiyono. (2011). Metode penelitian kuantitatif, kualitatif dan $R \& \mathcal{E}$. Bandung: Alfabeta.

Triawan, F., Suroso, \& Djoko S. A. (2012). Studi kapasitas pemerintah daerah dalam pengurangan risiko bencana gempa bumi. studi kasus: Kota Pariaman, Sumatera Barat. Bandung: Perencanaan dan Pengembangan Kebijakan ITB.

Undang-Undang Republik Indonesia Nomor 24 Tahun 2007 tentang Penanggulangan Bencana. Jakarta.

UNDP. (2009). Basics of capacity development for disaster risk reduction. Geneva, Switzerland: UNDP-CaDRi.

Wirawan. (2011). Evaluasi: Teori, model, standar, aplikasi, dan profesi. Jakarta: PT Raja Grafindo Persada. 